\title{
Ultrastructural localisation of muramidase in the human synovial membrane
}

\author{
P I MAPP AND P A REVELL
}

From the Bone and Joint Research Unit, and Department of Morbid Anatomy, The London Hospital Medical College, Turner Street, London

SUMmARY The synovial intimal cell layer comprises two morphological types of cell, A and $\mathrm{B} \frac{\varrho}{\overline{0}}$ with an intermediate type also postulated. Type A cells show features in common with other cell\& of the mononuclear phagocyte system, while type B cells appear similar to fibroblasts and are assumed to have synthetic activity. Muramidase is a marker of mononuclear phagocytic cells, anळ we have investigated the synovial membrane for the presence of this enzyme in cells by at immunogold labelling technique. Muramidase was localised within intracytoplasmic vacuoles in subintimal macrophages and type A synoviocytes. This finding provides further evidence that type A cells are closely related to macrophages.

Key words: electron microscopy, synoviocytes, lysosomes, enzyme production.

The surface of the synovial membrane is covered by a layer of intimal cells (synoviocytes), which are increased in number in various pathological conditions. Two main types of synovial intimal cell are recognised by electron microscopy, types $A$ and $B$, though an intermediate cell, sometimes called $A B$, has also been described.' The type $A$ cell is characterised by prominent Golgi apparatus, many vesicles and vacuoles, and sparse rough endoplasmic reticulum, whereas the type $B$ cell is well endowed with rough endoplasmic reticulum, but Golgi complexes, vesicles, and vacuoles are not abundant.

Hyperplasia of the intimal cell layer in conditions such as rheumatoid arthritis (RA) is considered to be due to an increase in type $B$ and $A B$ cells, ${ }^{23}$ although others believe that type A cells predominate. ${ }^{4}$ The manner in which the number of synoviocytes is increased is not yet understood. Synoviocytes may be derived from a common precursor which multiplies locally, ${ }^{5-7}$ but evidence has been presented more recently for a bone marrow origin for type A cells. ${ }^{89}$

The monocyte/macrophage lineage of cells contains significant amounts of the enzyme muramidase (EC 3.2.1.17). The synthesis and secretion of the

Accepted for publication 11 June 1986.

Correspondence to Mr P I Mapp, Bone and Joint Research Unit, The London Hospital Medical College, Turner Street, London E1 2AD. enzyme by mononuclear phagocytes in vitro has been demonstrated by Gordon and colleagues. ${ }^{10} \frac{\mathrm{O}}{\mathrm{O}}$ The enzyme has subsequently been used as a marken for cells of monocyte/macrophage lineage in im- $-\frac{\pi}{2}$ munohistochemical studies. ${ }^{11-13}$ Reports of the ultrastructural distribution of muramidase are few⿳ and relate to tissues where the concentration of the enzyme is very high, for example, in Paneth cells of the gastric mucosa. ${ }^{14}$

Muramidase has been employed in the presento study as a marker of macrophages in the synoviab membrane in order to examine further the possibil ity that synovial intimal cells are linked to theo monocyte/macrophage system, on the basis of shared enzyme expression with these cells. ${ }^{15}$ ? Although muramidase is also present in polymor $\rightarrow$ phonuclear leucocytes (PMNs), these may be read을 ily distinguished on a morphological basis from other cell types. We have studied the distribution of cells containing muramidase in synovial lining with elec $\tilde{O}^{\circ}$ tron microscopical methods in order to determinew which type of synoviocyte contains the enzyme.

\section{Materials and methods}

Synovial specimens from 11 patients, eight with ${ }^{\text {? }}$ rheumatoid arthritis and three with osteoarthritis (see Table 1 for clinical details) were fixed in $1 \% \frac{\mathrm{O}}{\mathrm{D}}$ glutaraldehyde in $0.1 \mathrm{M}$ phosphate buffer for twof hours at room temperature and washed in phos- -2 
Table 1 Summary of the clinical details of those patients whose synovial membranes were studied using immunoelectron microscopy

\begin{tabular}{lllllll}
\hline $\begin{array}{l}\text { Patient } \\
\text { No }\end{array}$ & $\begin{array}{l}\text { BJRU } \\
\text { No }\end{array}$ & $\begin{array}{l}\text { Age } \\
\text { (years) }\end{array}$ & Sex & Joint & Source & Diagnosis \\
\hline 1 & $70 / 84$ & 58 & M & Knee & S* & RA \\
2 & $91 / 84$ & 76 & F & Knee & S & RA \\
3 & $104 / 84$ & 51 & M & Knee & S & RA \\
4 & $109 / 84$ & 66 & F & Knee & S & RA \\
5 & $119 / 84$ & U $^{*}$ & M & Ankle & S & RA \\
6 & $131 / 84$ & 59 & F & Knee & S & RA \\
7 & $132 / 84$ & 55 & F & Knee & S & RA \\
8 & $86 / 85$ & 76 & F & Knee & S & RA \\
9 & $73 / 84$ & 60 & F & Knee & S & OA \\
10 & $87 / 84$ & 48 & F & Hip & S & OA \\
11 & $85 / 85$ & U & F & Hip & S & OA \\
\hline
\end{tabular}

${ }^{*} \mathrm{U}=$ unknown; $\mathrm{S}=$ surgery.

phate buffered saline (PBS)' twice for 15 minutes. Excess reactive glutaraldehyde was neutralised by exposing blocks to $0.5 \mathrm{M}$ ammonium chloride in PBS for four hours. The blocks were washed again in PBS and partially dehydrated in graded concentrations of methanol, the temperature being decreased to $-30^{\circ} \mathrm{C}$ as the concentration of methanol was increased. The blocks were subsequently transferred to Lowicryl $\mathrm{K} 4 \mathrm{M}$ resin and polymerised at $-30^{\circ} \mathrm{C}$ by ultraviolet light. Silver coloured sections were mounted on Pioloform coated nickel grids and stained for immunoelectron microscopy by the immunogold method. Grids were floated on $1 \%$ bovine serum albumin (BSA) in PBS containing $0.1 \%$ Tween 20 , alone for five minutes and subsequently with rabbit antihuman muramidase antibody (DAKO) (1:8 or 1:16 titrated to optimal dilution) in the BSA/PBS Tween 20 diluent for two hours at room temperature. The grids were then washed twice in PBS and probed with a goat antirabbit-gold conjugate of $15 \mathrm{~nm}$ diameter (Jannsen) for one hour at room temperature. Grids were washed again in PBS and then distilled water, and counterstained with $5 \%$ aqueous uranyl acetate. Control sections were performed by omission of the primary antibody and by inclusion of irrelevant rabbit antibody, in this case rabbit antiMycobacterium paratuberculosis (DAKO).

\section{Results}

Examination of the intimal cell layer in all cases showed the localisation of muramidase (seen as gold particles) to intracytoplasmic vacuoles in cells which were morphologically type A synoviocytes (Fig. 1). In contrast, the type B cells showed no evidence of the presence of the enzyme (Fig. 2). Preservation of the fine detail was somewhat variable in these surface cells, but the vacuoles containing gold particles in the better preserved intimal cells appeared to be primary lysosomes (Fig. 3), and these did not appear in any of the type B cells. The degree of preservation did not allow clear visualisa-

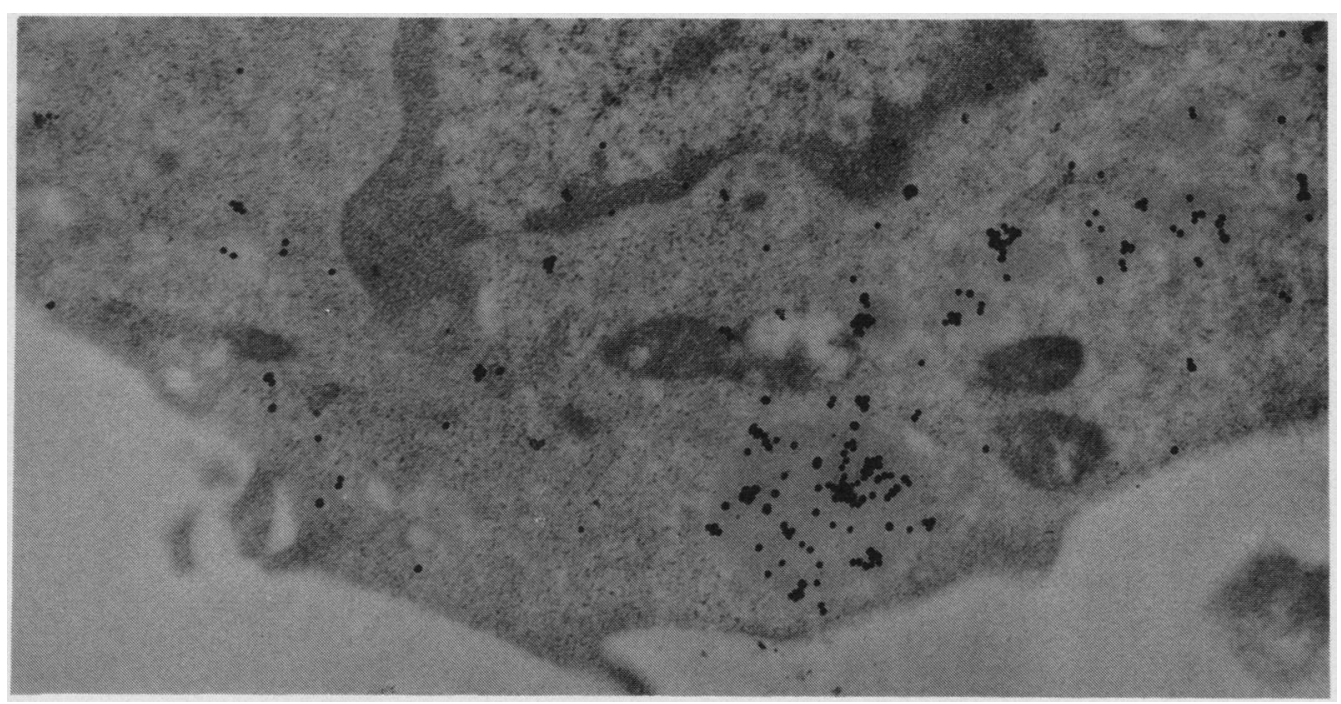

Fig. 1 Photomicrograph showing part of a type A synovial intimal cell. Muramidase is confined to cytoplasmic lysosomal structures. (Immunogold for muramidase). 
32 Mapp, Revell

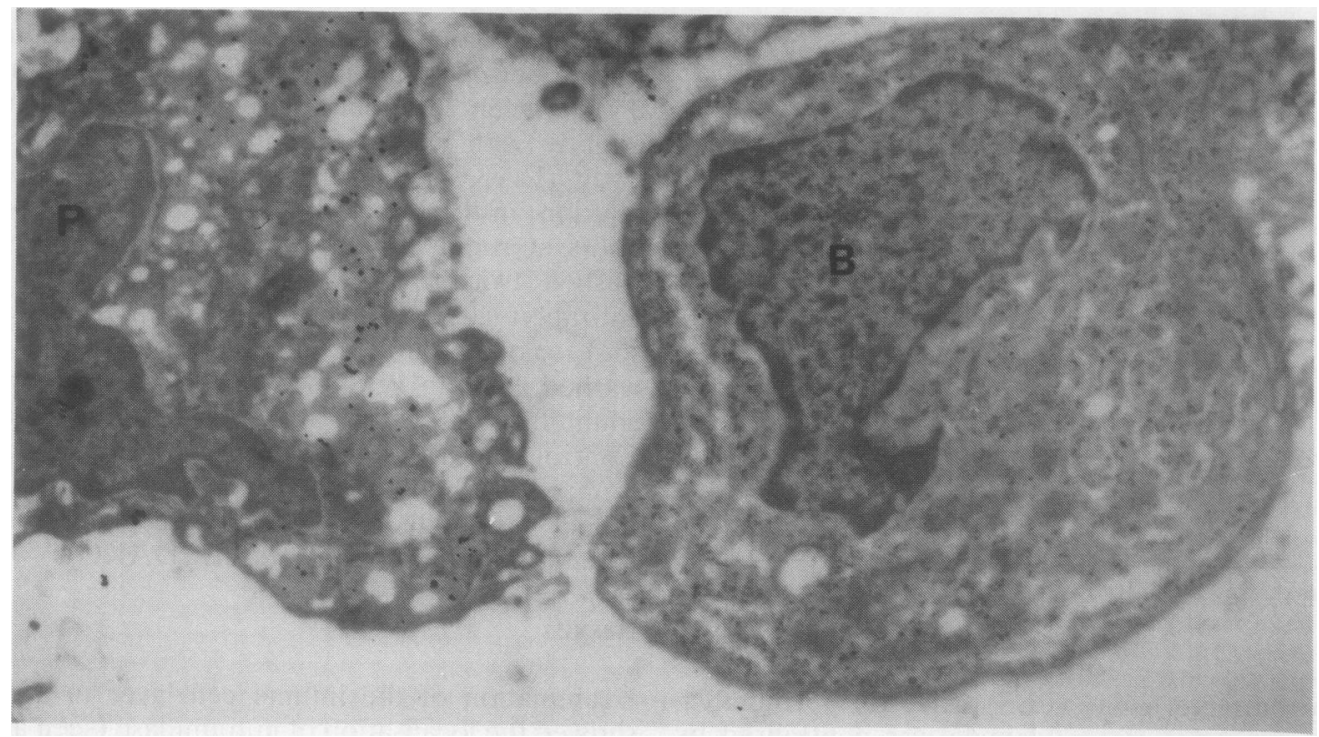

Fig. 2 Photomicrograph showing the absence of staining for muramidase in type B synovial intimal cell $(B)$ contrasting sharply with adjacent polymorphonuclear leucocyte $(P)$. (Immunogold for muramidase).

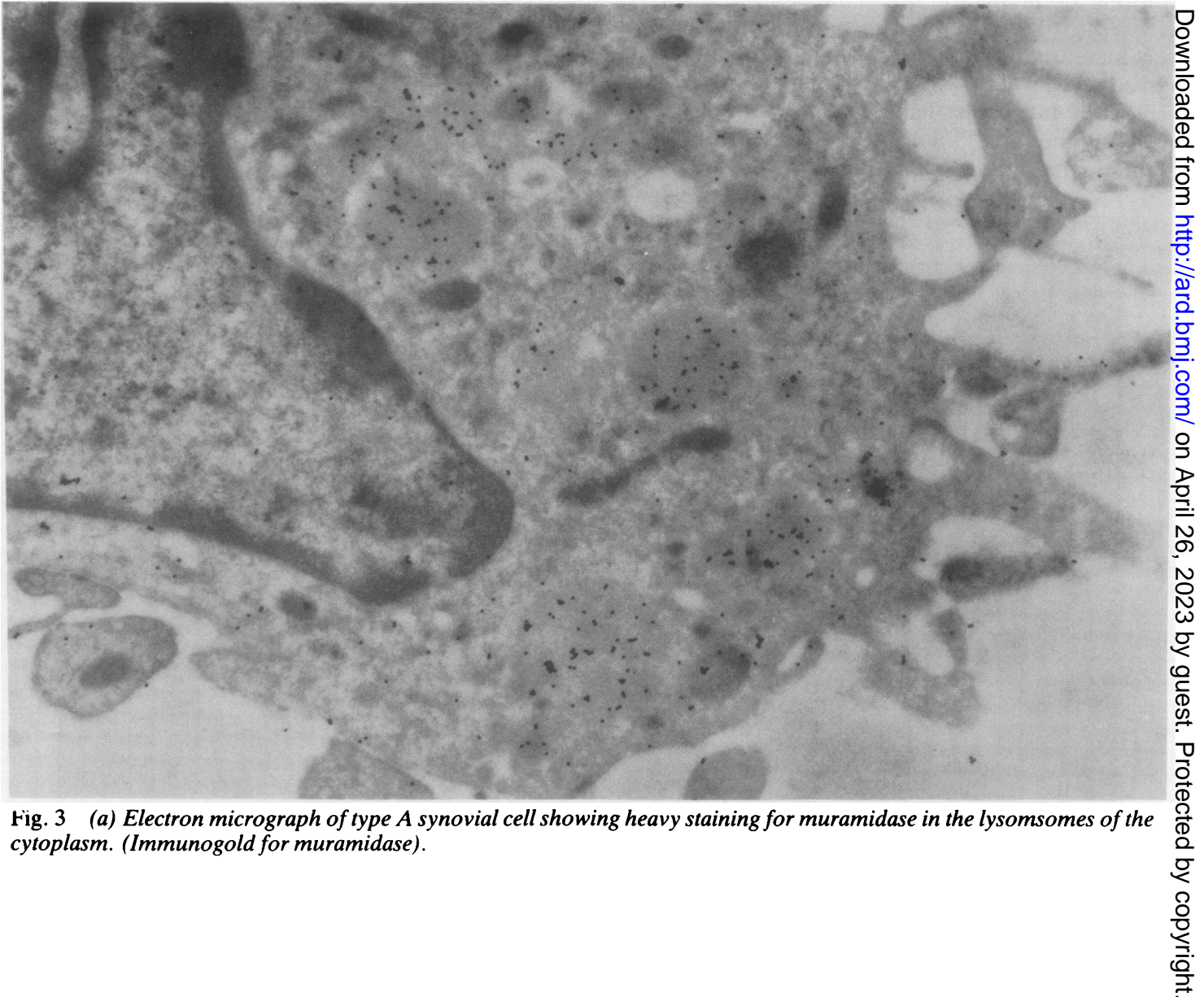




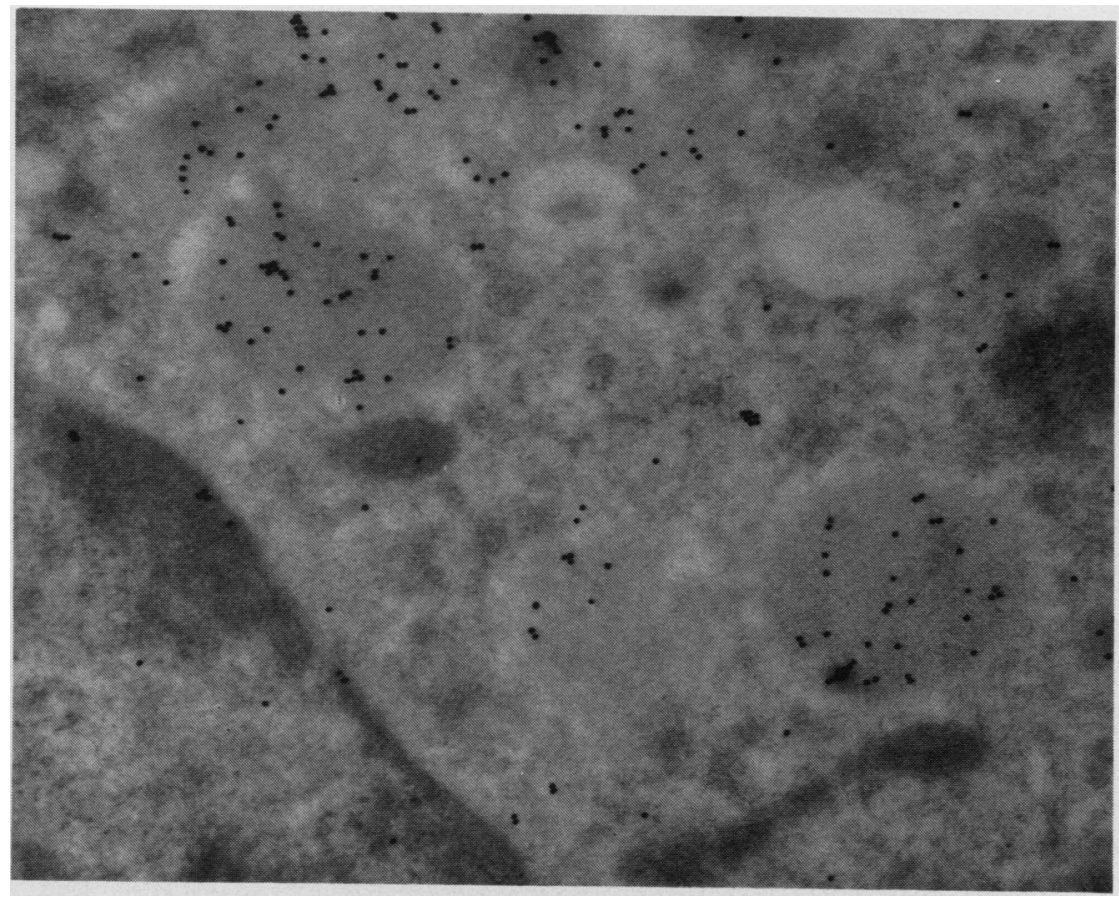

Fig. 3 (b) High power view of type A synovial cell showing individual lysosomes with localisation of gold particles. (Immunogold for muramidase).

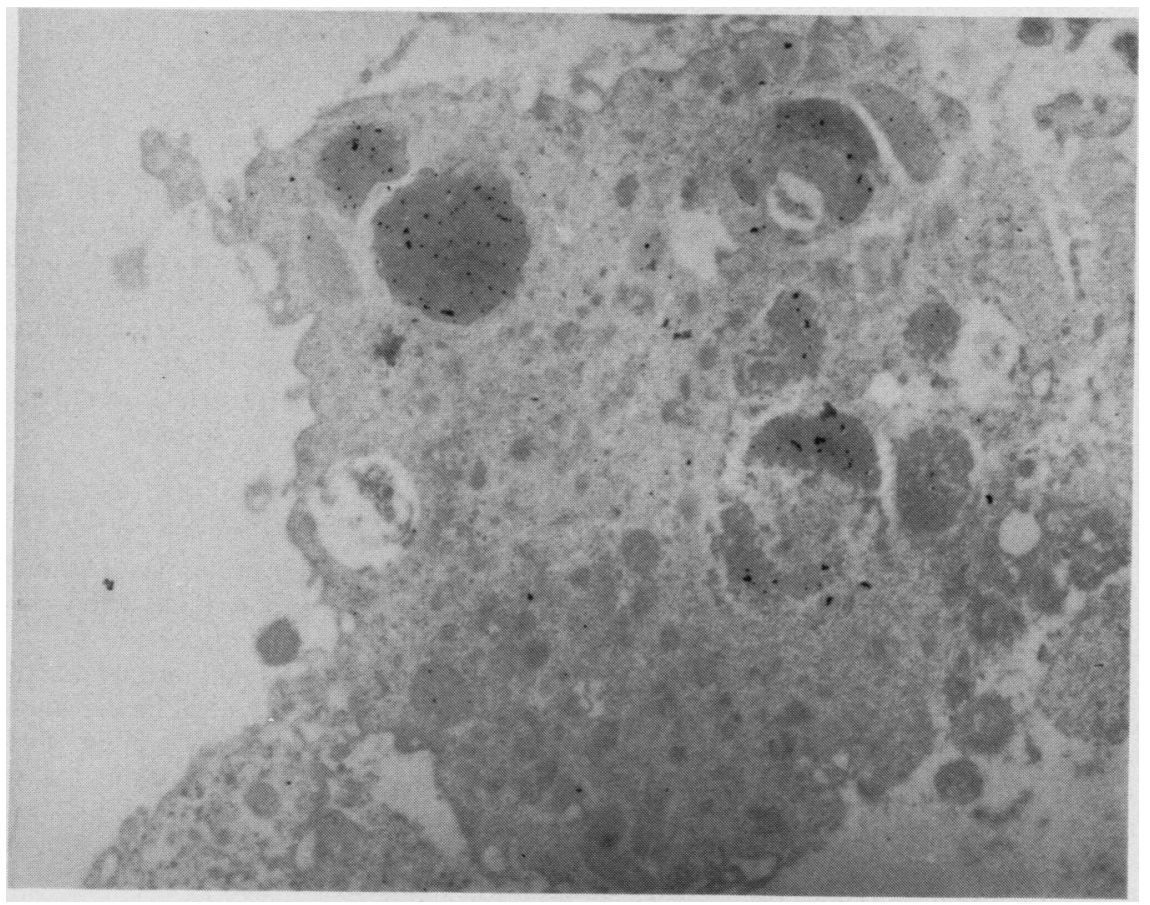

Fig. 4 Phagocytic vacuoles in type A lining cell containing remnants of erythrocytes. The presence of iron in the vacuoles was confirmed by $x$ ray microprobe analysis. (Immunogold for muramidase). 


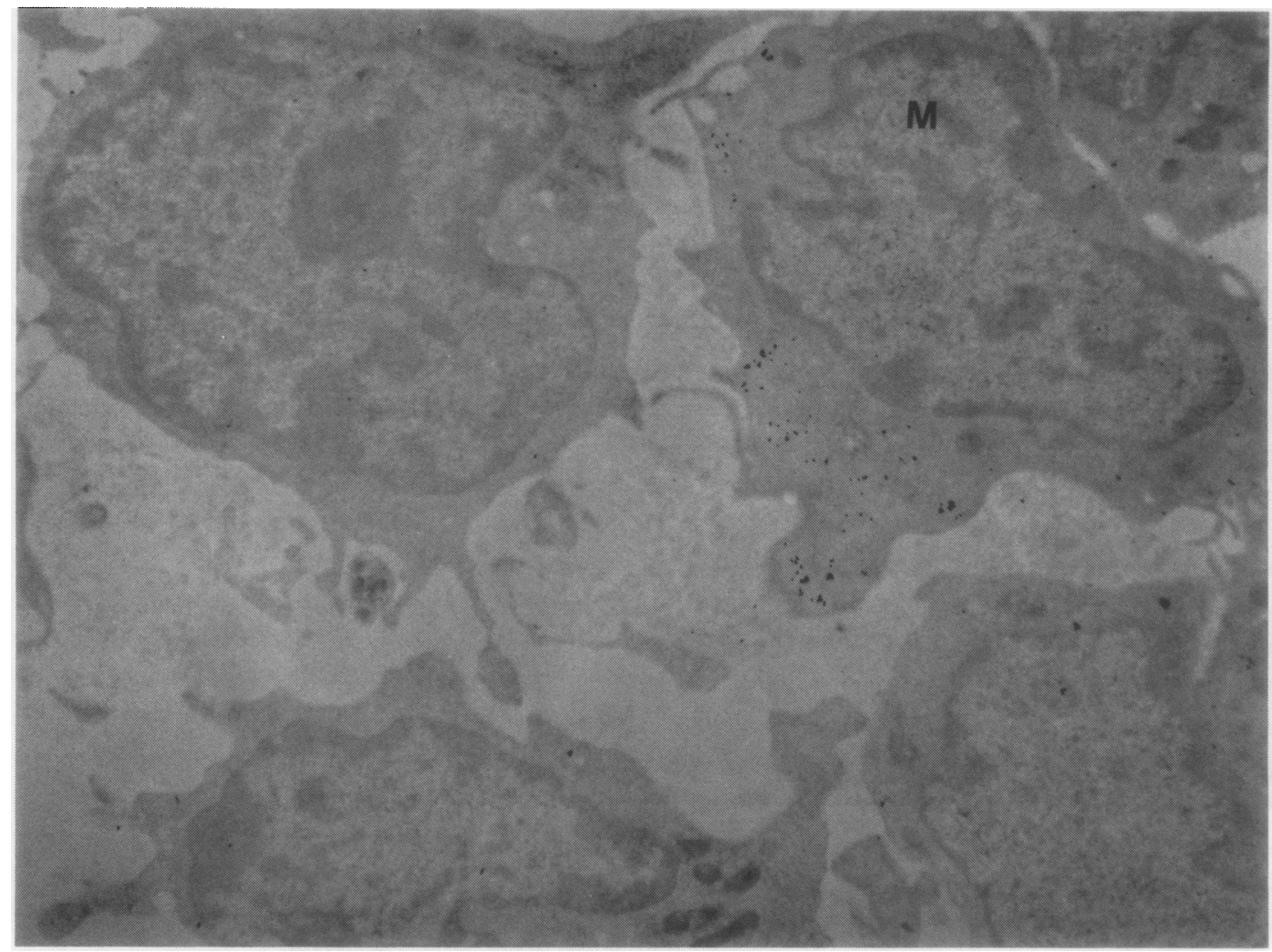

Fig. 5 Positive cell containing muramidase, macrophage (M), in a group of infiltrating cells of a perivascular cuff. Note absence of staining of surrounding cells. (Immunogold for muramidase).

tion of components such as Golgi apparatus. Localisation of gold probe to lysosomes would imply the production of the enzyme by the type A cells. The type A cells all showed expression of muramidase, but in some specimens many empty cytoplasmic vacuoles were observed, and label for the enzyme was markedly decreased in these sections. Muramidase was often localised to phagocytic vacuoles containing iron, the presence of which was confirmed by $x$ ray microprobe analysis (Fig. 4).

Two types of subintimal cell were labelled, namely infiltrating macrophages and PMNs. The macrophages were closely associated with other infiltrating cells which showed no expression of the enzymes (Fig. 5) and which were presumably lymphocytes. Closer examination of the subintimal macrophages also showed localisation of the gold probe to discrete vacuoles within the cytoplasm having morphology consistent with primary lysosomes (Fig. 6).

In addition to the subintimal macrophages the
PMNs also showed strong expression of murami dase, both within vessels (Fig. 7) and also in the subintimal tissues. Marking for muramidase showed. a surprising number of PMNs to be present in the synovial tissue, and they were often seen engulfing electron dense fibrous material. Control sections performed with rabbit anti-Mycobacterium para? tuberculosis antibody showed no staining.

\section{Discussion}

The distribution of muramidase in synovial tissue of patients with osteoarthritis and RA has been pre $-\omega$ viously described at the light microscope level. ${ }^{16}$ i Muramidase was found in PMNs, subintimal macro은 phages, and a proportion of the cells in the lining layer. ${ }^{16}$ Their data, however, did not allow cleat identification of the cell type which stained positively. We confirmed these findings ${ }^{17}$ but werêे unable to show any difference in the distribution of cells containing muramidase in RA, ankylosing 


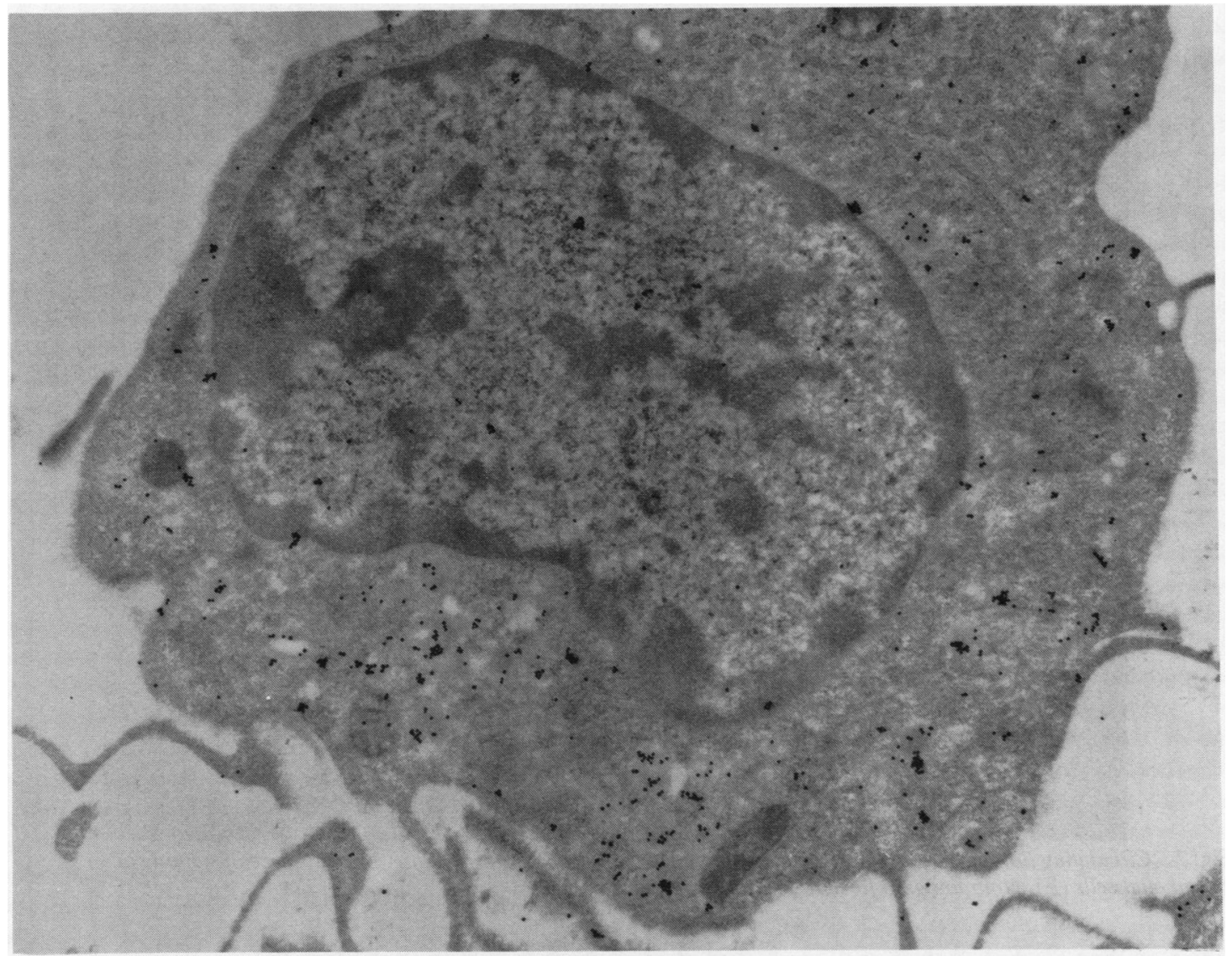

Fig. 6 Infiltrating macrophage showing numerous gold particles localised to lysosomal structures in the cytoplasm.

(Immunogold for muramidase).

spondylitis, psoriatic arthritis, or Reiter's syndrome. Using the peroxidase-antiperoxidase technique ${ }^{18}$ and routinely processed formaldehyde fixed tissue, intracellular staining of infiltrating macrophages appeared to be part granular and part cytoplasmic.

Further studies suggested that the proportion of lining cells which stained positively for muramidase might be dependent on disease activity, though these authors were also unable to identify the positive lining cells morphologically. ${ }^{19}$

The use of the immunogold technique has allowed the identification of the type A synovial intimal cells as the cells containing muramidase. In the specimens studied we found muramidase positive intimal cells in all cases. It is clear, however, that in some cases there was considerable extraction of cell contents during processing as evidenced by extensive vacuolated areas where no electron opaque material could be observed. This probably accounts for the failure of a small proportion of type A intimal cells to stain positively for muramidase. Muramidase having a molecular weight of only 14 $\mathrm{kD}$ would be prone to leaching, ${ }^{20}$ particularly at the intimal cell surface, by contact with the aqueous fixatives as indicated by Reitamo. ${ }^{21}$ Despite this, we believe we have provided evidence for the presence of muramidase, a macrophage marker, in type A synoviocytes. The possibility of secondary uptake of the muramidase by the synovial type $A$ cells seems unlikely since the enzyme was localised to primary rather than secondary lysosomes.

Briggs and colleagues surveyed all blood and bone marrow cells and showed that of the cell types examined, not only the monocytes, but also polymorphonuclear neutrophils (PMNs) contained muramidase activity. ${ }^{22}$ Baggiolini and colleagues 


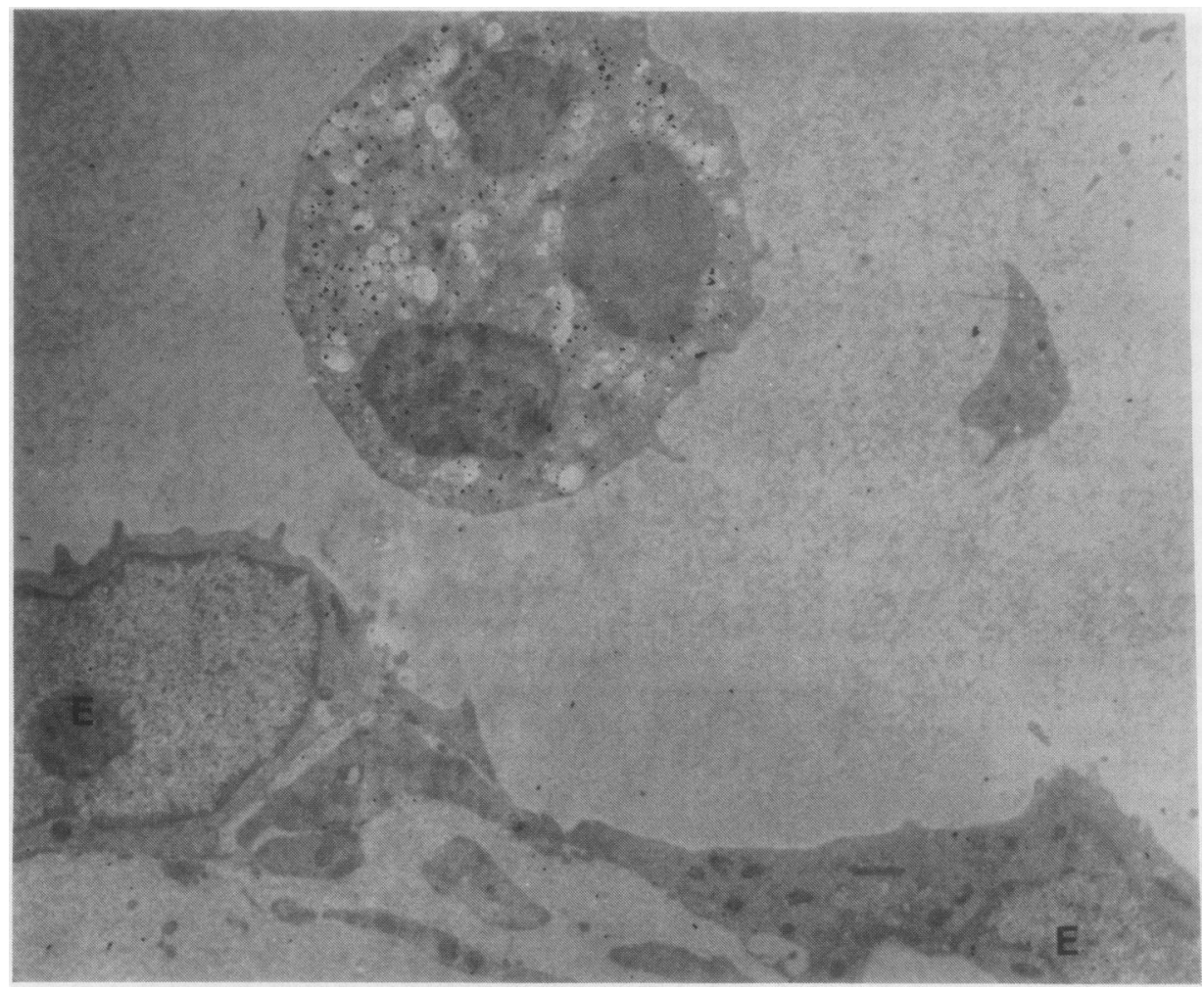

Fig. 7 Circulating polymorphonclear leucocyte showing localisation of muramidase. Note absence of staining in endothelial cells (E). (Immunogold for muramidase).

showed that in PMNs the enzyme was located in both the primary and secondary granules. ${ }^{23}$

In the subintimal tissue muramidase was localised to PMNs and macrophages as has been shown previously by light microscopy. ${ }^{24}$ As expected from these studies the concentration of muramidase in the PMNs was particularly high and clearly shown in sectional fractions of PMNs as well as whole cells. The number of PMNs thus demonstrated in the subintimal tissue was considerable, particularly in the rheumatoid specimens. This observation is consistent with the large number of polymorphs found in the inflammatory fluids in $\mathrm{RA},{ }^{25}$ which must migrate from the circulation, through the synovial tissue, to the joint space, and the demonstration of PMNs by light microscopy using monoclonal antibodies. ${ }^{26}$

Macrophages in the subintimal tissue were often in close apposition to other cells in 'perivascular cuffs'. The presence of these cells in this position would indicate their arrival from the circulation. These cells are thought to be active in the presentation of antigen to activated lymphocytes.
It has been suggested by experimental studies that the synovial intimal cell layer contains macrophages. ${ }^{89}$ Immunohistochemical studies have shown positive staining of a proportion of these cells for HLA-DR antigen ${ }^{27-31}$ and macrophage monoclonal antibody markers. ${ }^{31}{ }^{32}$ All these studies have been performed at light microscope level and, therefore, have not enabled the identification of the cells as type A or B synoviocytes, or as other cells which are infiltrating the synovial surface cell layer.

The ultrastructural demonstration of the enzyme of muramidase in both the subintimal macrophages $N$ which have presumably migrated from the circula- N tion, and in the lysosomes of type A synoviocytes $\underset{\sigma}{\sigma}$ offers further evidence for a monocyte/macrophage lineage for the type A synoviocyte, though it is still not possible to state whether one cell (the macrophage) becomes the other (the synoviocyte).

\section{References}

1 Ghadially F N. Fine structure of synovial joints. London: Butterworth, 1983. 
2 Ghadially F N. Overview article: the articular territory of the reticuloendothelial system. Ultrastruct Pathol 1980; 1: 249-64.

3 Klein W, Rosenbauer K A, Rupprecht L, Kramer J, Huth F. Beitrag zur kenntnis der juvenilen monartikularen rheumatoiden Arthritis. Virchows Arch Pathol Anat 1972; 357: 359-67.

4 Wynne-Roberts C R, Anderson C. Light- and electronmicroscopic studies of normal juvenile human synovium. Semin Arthritis Rheum 1978; 7: 279.

5 Barland P, Novikoff A B, Hammerman D. Electron microscopy of the human synovial membrane. J Cell Biol 1962; 14: $207-20$.

6 Kinsella T D, Baum J, Ziff M. Studies of isolated synovial lining cells of rheumatoid and non-rheumatoid synovial membranes. Arthritis Rheum 1970; 13: 734-52.

7 Fell H B, Glauert A M, Barratt M E J, Green R. The pig synovium. 1 The intact synovium in vivo and in organ culture. $J$ Anat 1976; 122: 663-80.

8 Dreher R. Origin of synovial type A cells during inflammation and experimental approach. Immunobiology 1982; 161: 232-45.

9 Edwards J C W, Willoughby D A. Demonstration of bone marrow derived cells in synovial lining by means of giant intracellular granules as genetic markers. Ann Rheum Dis 1982; 41: $177-82$.

10 Gordon S, Todd J, Cohn Z A. In vitro synthesis and secretion of lysozyme by mononuclear phagocytes. J Exp Med 1974; 193: 1228-48.

11 Mason D Y, Taylor C R. The distribution of muramidase (lysozyme) in human tissues. J Clin Pathol 1975; 28: 124-32.

12 Malmquist J, Thorell J I, Wollheim F A. Lactofernin and lysozyme levels in arthritis exudates. Acta Med Scand 1977; 202: 313-8.

13 Klockars M, Reitamo S. Tissue distribution of lysozyme in man. J Histochem Cytochem 1975; 23: 932-40.

14 Erlandsen S L, Parsons J A, Taylor T D. Ultrastructural immunocytochemical localisation of lysozyme in the Paneth cells in man. $J$ Histochem Cytochem 1974; 22: 401-13.

15 Van Furth R, Raeburn J A, van Zwet T L. Characteristics of human mononuclear phagocytes. Blood 1979; 54: 485-500

16 Fitz P, Muller J, Braun U, et al. Distribution of lysozyme in synovial tissue of patients with osteoarthritis and rheumatoid arthritis demonstrated by different enzyme histochemical techniques. Rheumatol Int 1982; 2: 41-7.

17 Palmer D G, Selvendran Y, Allen C, Revell P A, Hogg N. Features of synovial membrane identified with monoclonal antibodies. Clin Exp Immunol 1985; 59: 529-38.

18 Sternberger L A, Hardy P H, Cuculis J J, Meyer H G. The unlabelled antibody enzyme method of immunohistochemistry.
Preparation and properties of soluble antibody-antigen complex (horseradish peroxidase-antihorseradish peroxidase) and its use in the identification of spirochetes. J Histochem Cytochem 1970; 18: $315-33$

19 Geiler G, Riedel U. Detection by the PAP technique of lysozyme-containing synoviocytes and their quantity in rheumatoid arthritis and osteoarthritis. Histochem $J$ 1985; 17: 562-3.

20 Petit J F, Jolles, P. Purification and analysis of human saliva lysozyme. Nature 1963; 200: 168-9.

21 Reitamo S. Lysosome antigenicity and tissue fixation. Histochemistry 1978; 55: 197-207.

22 Briggs R S, Perillie P E, Finch S C. Lysozyme in bone marrow and peripheral blood cells. J Histochem Cytochem 1966; 14: 167-70.

23 Baggiolini M, Hirsch J G, DeDuve C. Resolution of granules from human neutrophil leucocytes into distinct populations by zonal sedimentation. J Cell Biol 1969; 40: 529-41.

24 Pruzanski W, Katz A, Ogryzlo M A. The source of lysozyme in synovial fluids. J Rheumatol 1974; 1 (suppl 1): 44.

25 Klockars M, Pettersson T. Lysozyme concentrations in synovial fluid, pleural fluid and thoracic duct lymph in rheumatoid arthritis. Scand J Rheumatol 1985; 14: 69-75.

26 Revell P A, Hogg N, Palmer D G. Granulocytes in the rheumatoid synovial membrane demonstrated by monoclonal antibodies [Abstract]. $\mathrm{Br} J$ Rheumatol 1985; 24: 79.

27 Klareskog L, Forsum U, Tjernlund U, Kabelitz D, Wigren A. Appearance of anti HLA-DR reactive cells in normal and rheumatoid synovial tissue. Scand J Immunol 1981; 14: 183-92.

28 Poulter L W, Duke O, Hobbs S, Janossy G, Panayi G. Histochemical discrimination of HLA-DR positive cell populations in normal and arthritis synovial lining. Clin Exp Immunol 1982; 48: 381-8.

29 Meijer C J L M, de Graaf-Reitsma C B, Lafeber G A J M, Cats A. In situ localisation of lymphocyte subsets in synovial membranes of patients with RA with monoclonal antibodies. $J$ Rheumatol 1982; 9: 359-65.

30 Forre $\mathrm{O}$, Thoen $\mathrm{J}$, Lea $\mathrm{T}$, et al. In situ characterisation of mononuclear cells in rheumatoid tissues using monoclonal antibodies. Scand J Immunol 1982; 16: 315-9.

31 Burmester G R, Dimitriu-Bona A, Waters S J, Winchester R J. Identification of three major synovial lining cell populations by monoclonal antibodies directed to Ia antigens and antigens associated with monocytes/macrophages and fibroblasts. Scand J Immunol 1983; 17: 69-82.

32 Hogg N, Palmer D G, Revell P A. Intimal cells of the synovial membrane identified by monoclonal antibodies [Abstract]. $\mathrm{Br} J$ Rheumatol 1985; 24: 79. 